BNWL-2012

UC-20

\title{
Fuel Procurement for First Generation Fusion Power Plants
}

by

B. F. Gore

P. L. Hendrickson

September 1976

Prepared for the Energy Research and Development Administration under Contract E(45-1)-1830 
NOTICE

This report was prepared as an account of work sponsored by the United States Government. Neither the United States nor the Energy Research and Development Administration, nor any of their employees, nor any of their contractors, subcontractors, or their employees, makes any warranty, express or implied, or assumes any legal liability or responsibility for the accuracy, completeness or usefulness of any imformation, apparatus, product or process disclosed, or represents that its use would not infringe privately owned rights.

\author{
PACIFIC NORTHWEST LABORATORY \\ operated by \\ BATTELLE \\ for the
}

ENERGY RESEARCH AND DEVELOPMENT ADMINISTRATION

Under Contract E(45-1)-1830

\author{
Printed in the United States of America \\ Available from \\ National Technical information Service \\ U.S. Department of Commerce \\ 5285 Port Royal Road \\ Springfield, Virginia 22751
}

Price: Printed Copy 55.00; Microfiche $\mathbf{3 2 . 2 5}$ 


\section{FUEL PROCUREMENT}

\section{FOR FIRST GENERATION FUSION POWER PLANTS}

by

B. F. Gore

P. L. Hendrickson

September 1976

Battelle

Pacific Northwest Laboratories

Richland, Washington 99352 


\section{PREFACE}

Fusion reactor technology has developed far enough to expect laboratory demonstration of practical levels of fusion employing the D-T reaction to occur in the early 1980s. Following that demonstration, and depending upon the national priorities for energy from D-T fusion, construction and operation of experimental reactors and demonstration power reactors could occur before the end of this century. Operation of the first commercial power plants could then follow, starting about 2010 .

Development and adoption of a new power system eventually will require a description of the environmental effects in an environmental statement providing a comparison to the effects of competitive systems. In anticipation of that statement, an environmental analysis (BNWL-2010) has been prepared for the ERDA Division of Magnetic Fusion Energy. That analysis estimates the environmental effects of constructing and operating $D-T$ fusion reactors as an economically competitive source of electricity in the 21 st century.

The analysis has four primary purposes:

1. To describe the general nature of the environmental effects,

2. To determine current ability to estimate the effects,

3. To determine methods for reducing the effects, and

4. To determine research necessary for increasing capability to define and reduce the effects.

Timely identification of needed research and methods for reducing effects will permit the performance of that research and the revision of conceptual fusion power plant designs before preparation of the program environmental statement. This would improve the quality of the environmental statements and could reduce the estimated adverse environmental effects due to fusion power plants.

The environmental analysis (BNWL-2010) concludes that the following assumed characteristics are the best set for the first operating fusion power plants:

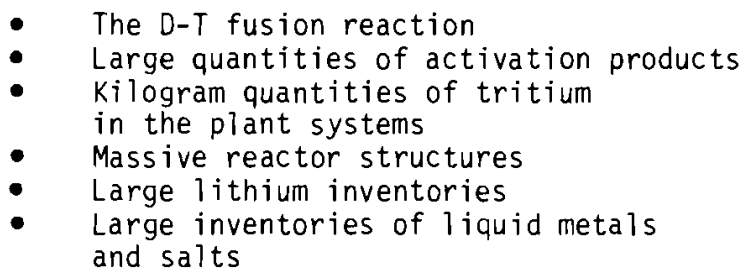

- Standard electricity generation - Standard radioactive waste systems - Large magnetic fields

- A self-contained fuel cycle - Rural siting

Using these characteristics a reference reactor was analyzed to determine the environmental effects by using available concepts of plant subsystems designs that control interactions with the environment or by assumption that best current technology would be used in subsystems design. Because this analysis does not take into account advances in both fusion and waste control technology during the next thirty years, the estimated effects probably are significantly higher than the actual effects will be for the first fusion power plants. The estimated environmental effects should be interpreted only as being the probable upper limit for the actual effects. 
Preparation of the fusion power plant environmental analysis required development and use of specially developed data and analysis methods not used in the preparation of current environmental statements for fossil and fission power plants. These data and analysis requirements are documented in a series of reference topical reports to make this information publicly available and to assure understanding of the basis for the conclusions made in the environmental analysis. These reference topical reports summarize the state-of-the-art as applicable to preparation of environmental statements for fusion power plants. They present the data and analytical techniques used in the environmental analysis to estimate the interactions with the environment and the resultant environmental effects. This information then was analyzed for adequacy and the need was determined for additional research to assure satisfactory ability to prepare environmental statements for the fusion development program and experimental facilities in the early 1980s. Estimated environmental effects are presented in these reference documents only as necessary to illustrate use of the data and analytical techniques.

This report is one of those reference documents for the environmental analysis. The other documents in this series contain more details of the power plant concepts and the probable environmental effects of fusion power plants with the assumed characteristics listed above. These documents are available through the National Technical Information Service:

An Environmental Analysis of Fusion Power to Determine Related R\&D Needs, BNWL-2010

Review of Fusion Research Program: Historical Sumary and Program Projections, BNWL-2011

Fuel Procurement for First Generation Fusion Power Plants, BNWL-2012

Current Fusion Power Plant Design Concepts, BNWL-2013

Reference Commerical Fusion Power Plants, BNWL-2014

Siting Commercial Fusion Power Plants, BNWL-2015

Materials Availability for Fusion Power Plant Construction, BNWL-2016

Projected Thermodynamic Efficiencies of Fusion Power Plants, BNWL-2017

Tritium Source Terms for Fusion Power Plants, BNWL-2018

Management of Nontritium Radioactive Wastes from Fusion Power Plants, BNWL-2019

Methodology for Estimating Radiation Doses Due to Tritium and Radiocarbon Releases, BNWL-2020

Magnetic Field Considerations in Fusion Power Plant Environs, BNWL-2021

Biological Effects of Tritium Releases from Fusion Power Plants, BNWL-2022

Biological Effects of Activation Products and Other Chemicals Released from Fusion Power Plants, BNWL-2023

Safety Review of Conceptual Fusion Power Plants, BNkL-2024

An Investigation of the Transportation Requirements of Fusion Power Plants, BNWL -2025

Considerations of the Social Impact of Fusion Power, BNWL-2026

Environmental Impacts of Nonfusion Power Systems, BNWL-2027

Environmental Cost/Benefit Analysis for Fusion Power Plants, BNWL-2028

Biomagnetic Effects: A Consideration in Fusion Reactor Development, BNWL-1973

An Analysis of Tritium Releases to the Atmosphere by a CTR, BNWL-1938 
CONTENTS

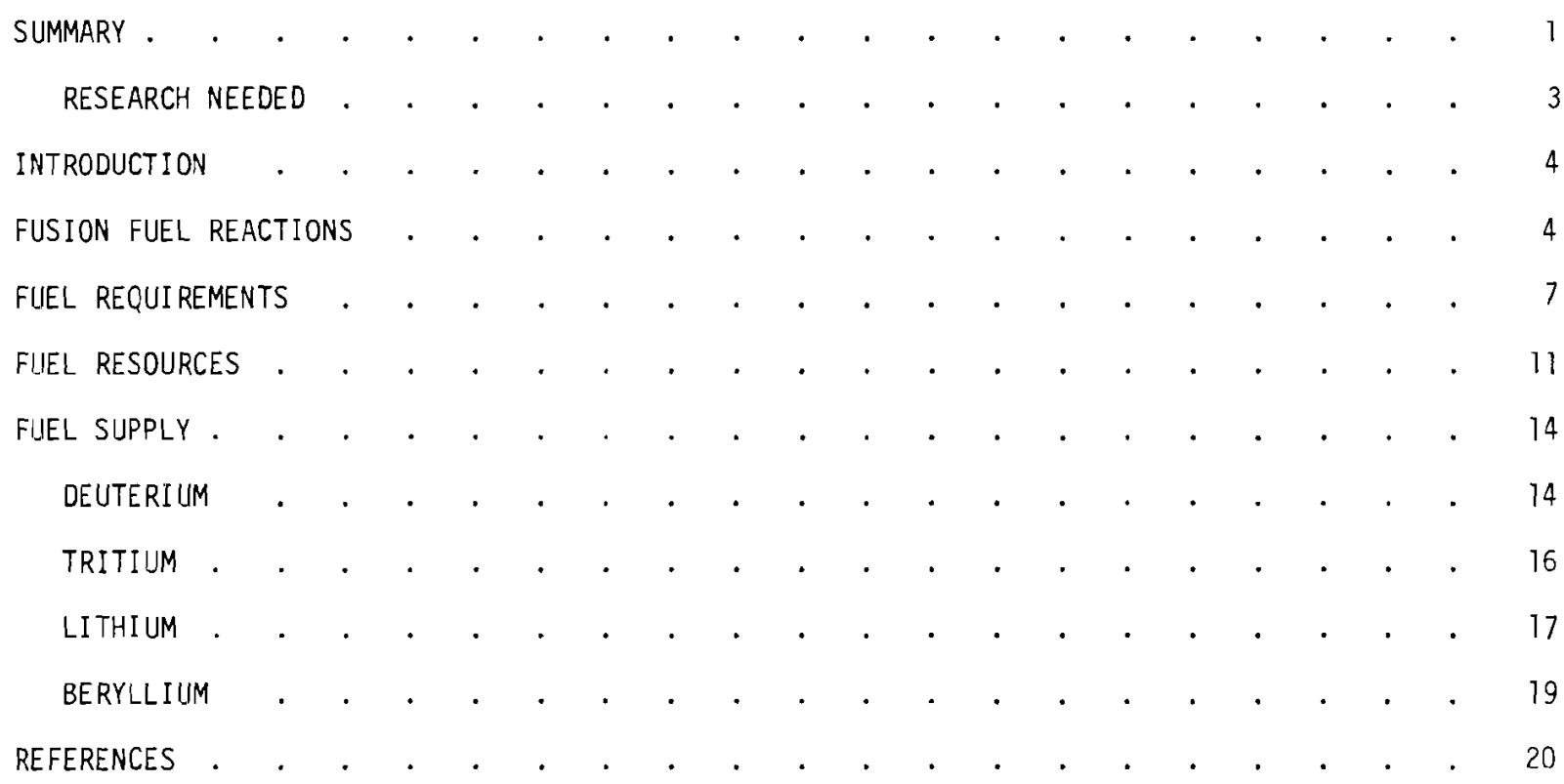




\section{SUMMARY}

The first generation fusion power plants are expected to use the deuterium-tritium (D-T) fuel reaction because it is the easiest to achieve. Plasma confinement and temperature requirements are the least stringent for this reaction. Tritium fuel will be bred in the reactor blanket from lithium. Some concepts use beryllium in the blanket to enhance tritium breeding because of its neutron multiplying properties.

Alternative fuel reactions include the D-D reaction, for which sufficient fuel is readily available to satisfy all of the U.S. energy needs for the foreseeable future. Other alternatives use nonradioactive fuel and produce nonradioactive reaction products whose energy is carried by charged particles and is therefore available for highly efficient direct conversion to electricity.

Deuterium - Deuterium fuel requirements for D-T fusion power plants are expected to range from 60 to not more than 200 kilograms per gigawatt electric-year (kg/GWe-yr). Generation of $10^{6}$ MWe would then require less than 200 metric tons of deuterium per year. This is an insignificant fraction of the deuterium content of the earth's water which is estimated to be about $10^{13}$ metric tons. An ample supply of deuterium for fusion power plants is thus assured for many centuries. One heavy water plant of the present commercial size could supply several times the deuterium required by $10^{6}$ MWe of fusion power plant electrical generating capacity. At present prices the cost of deuterium consumed would be $3 \times 10^{-3}$ mills per kilowatt hour (mills/kWh). The environmental impact of deuterium production is trivial.

Tritium - The only tritium expected to be purchased by a commercial fusion power industry is an inventory for the first plant, which will then breed an excess to supply succeeding reactors. The required tritium inventory for the first plant is not expected to exceed $24 \mathrm{~kg}$, which could be produced in fission reactors for the fusion power plant.

The maximum environmental impact of producing the tritium inventory for the first commercial fusion reactor would result from construction of a special fission reactor for the purpose. If production were accomplished in existing fission reactors, the primary impact would be that of incremental tritium releases due to escape from and processing of the target elements.

Lithium - Fusion reactors are expected to consume lithium (primarily ${ }^{6}$ Li) through nuclear reactions, and through required replacement of blanket materials damaged by radiation. The maximum consumption of ${ }^{6} \mathrm{Li}$ by nuclear reactions is estimated to be $340 \mathrm{~kg} / \mathrm{GWe}-\mathrm{yr}$. The annual maximum consumption due to blanket replacement is estimated to be $12,000 \mathrm{~kg} / \mathrm{GWe}$ of generating capacity, assuming no recycle of replaced material. If 90 percent recycle is assumed, a $10^{6}$ Me generating capacity would consume a maximum of 1,200 metric tons of ${ }^{6} \mathrm{Li}$ per year, which is roughly 0.5 percent per year of the ${ }^{6} \mathrm{Li}$ content of U.S. resources estimated recoverable at three times present prices. Furthermore, since only 7.5 percent of natural lithium is ${ }^{6} \mathrm{Li}$, the tails of the enrichment process would represent a feedstock for chemical uses of lithium of more than ten times the quantity of ${ }^{6} \mathrm{Li}$ consumed. Lithium resources therefore appear adequate to supply these consumptive uses of 1 ithium for more than a century of $10^{6}$ Mwe generation. 
Large inventories of natural lithium are required by power plant concepts that use liquid lithium metal as moderator, fertile material and primary coolant. Generating capacity of $10^{6}$ Mwe using this concept is expected to require between 500,000 and 1,200,000 metric tons of inventory. Although this would be about one-third of the estimated U.S. resource, consumption of this inventory would take place only by nuclear reactions, at the trivial rate of $340 \mathrm{~kg} /$ GWe-yr. Use of this inventory should be possible over and over again in many generations of power plants, assuming continuous purification and make up of the lithium consumed. Thus, U.S. $1 i$ thium resources appear capable of supplying $10^{6}$ MWe of fusion power plant electrical generating capacity for more than a century.

The maximum lithium inventory required for a single fusion power plant is of the same magnitude as present annual lithium production. However, production is increasing rapidly. If lithium enriched in ${ }^{6} \mathrm{Li}$ costs ten times as much as natural $1 i$ thium, the maximum cost due to ${ }^{6} \mathrm{Li}$ consumption and replacement (no recycle assumed) is estimated to be about $1 \mathrm{mill} / \mathrm{kWh}$. The principal environmental impact of lithium production is the land usage for mining or for brine concentration by evaporation. The actual availability of lithium for fusion reactors will depend on the use of lithium for other purposes prior to introduction of fusion power plants. This availability is considered in BNWL-2016.

Beryllium - Beryllium will be consumed by nuclear reactions, in designs that include it as a neutron multiplier in the reactor blanket, and by replacement of blanket materials damaged by radiation. The maximum consumption of beryllium due to nuclear reactions is estimated to be $260 \mathrm{~kg} /$ GWe-yr. The maximum consumption due to blanket replacement is estimated to be $10,700 \mathrm{~kg} / \mathrm{GWe}$ of generating capacity, assuming 90 percent recycle of replaced material.

A generating capacity of $10^{6}$ Mwe would consume up to 10,700 metric tons of beryllium per year, which is almost 4 percent per year of estimated U.S. resources. Furthermore, the inventory requirements for $10^{6}$ MWe of generating capacity using either molten salt (flibe) in the blanket or beryllium plus solid lithium compounds exceed or are comparable to estimated U.S. resources. (Since non-U.S. resources of beryllium are estimated to be less than twice U.S. resources, use of foreign resources does not appear practical.) Therefore, construction and operation of a $10^{6}$ Me generating capacity using beryllium appears to be highly unlikely in competition with demand from other industries. The potential for expansion of beryllium resources is discussed in BNWL-2016.

Present annual production of beryllium is somewhat smaller than the inventory required by either of the two power plant designs having the greatest requirements. Using present beryllium prices the maximum costs due to beryllium consumption and replacement (assuming 90\% efficient recycle) are estimated to be about half a mill per kWh.

Land disruption could be a large environmental impact of beryllium mining if it becomes necessary to utilize low grade ore. However, land reclamation is practiced in the industry. The toxicity of beryllium requires that care be taken in milling and fabrication processes. The industry has developed procedures to keep worker exposure and releases to the environment to acceptable levels. 


\section{RESEARCH NEEDED}

Studies of beryllium should be initiated to improve the estimates of the reserves and resources. Present annual use of beryllium is comparable to the inventory requirements for a single large fusion power plant. If new resources must be found, incentives will probably be required to spur commercial exploration appropriate to potential fusion demand levels. Development of reserves, production and fabrication capacity can take from 15 to 30 years. Prompt anticipatory action appears desirable.

Since the beryllium supply is uncertain it represents an uncertainty in quantifying the environmental impacts. Therefore, it would be useful if fusion reactor designers would give attention to minimizing the use of beryllium in their design, or to seeking substitute materials for beryllium in the reactor blanket. 
FUEL PROCUREMENT FOR FIRST GENERATION FUSION POWER PLANTS

\section{INTRODUCTION}

The provision of deuterium, tritium, lithium and beryllium fuel materials for fusion power plants is examined in this document. Possible fusion reactions are discussed for use in first generation power plants. Requirements for fuel materials are considered. A range of expected annual consumption is given for each of the materials for a 1000 megawatts electric (Mwe) fusion power plant. Inventory requirements are also given. Requirements for an assumed fusion power plant electrical generating capacity of $10^{6}$ MWe (roughly twice present U.S. generating capacity) are also given.

Requirements for fuel materials to supply $10^{6}$ Mie of generating capacity are then compared to U.S. resources. Reasons are given for concluding that resources are probably adequate to sustain this generating capacity for over a century, except when power plant designs require large beryllium inventories.

The supply industries are then examined for deuterium, lithium, and beryllium. Methods are discussed for producing the only tritium expected to be purchased by a commercial fusion industry-an initial inventory for the first plant. Present production levels and methods are described for deuterium, lithium and beryllium. The environmental impact associated with production of these materials is then discussed. The toxicity of beryllium is described, and methods are indicated to keep worker exposure to beryllium as low as achievable.

\section{FUSION FUEL REACTIONS}

Fusion reactions are nuclear reactions between light nuclei that release energy, and which yield product nuclei differing from the fuel nuclei. The reacting nuclei must collide very hard to undergo a fusion reaction and even then it is much more likely that they will simply scatter without reacting. The requirements of multiple, high-energy collisions of fuel nuclei are met in a plasma.

In a fusion reactor the fuel plasma must be hot enough to react. It must be dense enough that collisions are frequent and it must be held together long enough that more energy is released by fusion than is required to produce the plasma. Demonstration that this is possible is the nearterm goal of the fusion program.

The difficulty of plasma confinement increases with plasma temperature. Consequently, it is expected that the fusion reaction to be employed in the first generation fusion reactors will be the one having the lowest plasma temperature requirements. This is the reaction between the heavy isotopes of hydrogen, deuterium $\left(D\right.$, or $\left.{ }^{2} H\right)$ and tritium $\left(T\right.$, or $\left.{ }^{3} H\right)$. Each such reaction yields an alpha particle ( ${ }^{4} \mathrm{He}$ ) and a neutron plus 17.6 million electron volts (MeV) of energy;

$$
\mathrm{D}+\mathrm{T}+{ }^{4} \mathrm{He}+n+17.6 \mathrm{MeV} \text {. }
$$


Although this reaction is just one of many possible fusion reactions, it is expected to yield significant releases of fusion energy at plasma temperatures much lower than are required for the others. Plasma ignition (when energy losses are balanced by fusion energy deposition in the plasma) requires a plasma kinetic temperature of about 5 kiloelectron volt (keV) $\left(5.8 \times 10^{7}{ }^{\circ} \mathrm{C}\right)$ for the D-T reaction. (1)

Fuels considered for power plant use must be obtainable in large quantities at a relatively low cost per unit of electricity produced. While natural supplies of tritium which satisfy this criterion do not exist, it is possible to produce tritium from lithium via the reactions

$$
\begin{aligned}
& { }^{6} \mathrm{Li}+\mathrm{n} \rightarrow \mathrm{T}+{ }^{4} \mathrm{He}+4.8 \mathrm{MeV} \\
& { }^{7} \mathrm{Li}+\mathrm{n} \rightarrow \mathrm{T}+\mathrm{n}+{ }^{4} \mathrm{He}-2.5 \mathrm{MeV} .
\end{aligned}
$$

Because the $14 \mathrm{MeV}$ neutrons produced in D-T fusion exceed the $2.5 \mathrm{MeV}$ threshold for the ${ }^{7} \mathrm{Li}$ reaction, it is possible for a single fusion neutron to produce two atoms of tritium in lithium. This happens when an energetic neutron induces the ${ }^{7} L i$ reaction which emits a secondary neutron that induces the lithium reaction. Studies indicate that blankets can be designed for D-T fusion reactors which will breed tritium, producing more than enough to fuel the fusion reaction.

Deuterium exists in water with an isotopic abundance of 0.015 percent ensuring its availability and large reserves of lithium exist in the U.S. Production costs for deuterium and lithium are very low in relation to the worth of the power which can be generated from them. Thus, in addition to being the fuel in which fusion may be the easiest to achieve, deuterium and tritium bred from lithium satisfy the requirements for fuel for a large power industry.

Tritium breeding requires the production of slightly more than one tritium atom per fusion (on the average) despite losses of fusion neutrons through leakage and through captures by reactor materials other than $1 i$ thium. Besides use of the sequential ${ }^{7} \mathrm{Li},{ }_{\mathrm{Li}}$ reactions tritium breeding can be achieved with neutron-multiplying reactions in place of, or in addition to, the ${ }^{2} \mathrm{~L}$ reactions. The beryllium (Be) reaction

$$
\begin{aligned}
{ }^{9} \mathrm{Be}+n & +2 n+8_{\mathrm{Be}}-1.7 \mathrm{MeV} \\
10^{-16} \mathrm{sec} & \longrightarrow 2{ }^{4} \mathrm{He}+0.09 \mathrm{MeV}
\end{aligned}
$$

is an important example. Tritium breeding reactor blankets have been designed which include beryllium for $i$ ts neutron multiplying effect for various reasons. Some of these are: to allow design of a thinner blanket; to reduce the amount of 1 ithium needed by using enriched ${ }^{6} \mathrm{~L} i$; and to make up for neutron captures by other materials included in the blanket.

There are many other possible fusion reactions. Most prominent of these is the reaction:

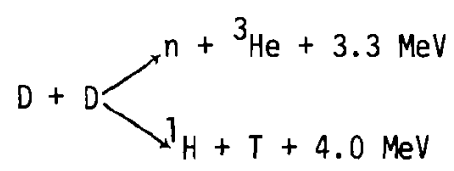


where the probabilities of each branch are approximately equal. The ignition temperature for this reaction is $28 \mathrm{keV}\left(3.2 \times 10^{8}{ }^{\circ} \mathrm{C}\right)$, nearly six times higher than required for D-T ignition. ( 1 ) The deuterium fuel for the $D-D$ reaction is universally available, and virtually inexhaustible. Hence, it represents a possible long-term solution to the world's energy needs. This reaction is also of interest because tritium need not be bred in the blanket, and the $2.5 \mathrm{MeV}$ neutrons produced are less penetrating, less damaging and cause less activation than the $14 \mathrm{MeV}$ neutrons from the $D-T$ reaction.

Each D-D fusion produces as a reaction product, either an ion of tritium or of ${ }^{3} \mathrm{He}$. The tritium ions may be consumed within the plasma via the D-T reaction. Furthermore, the ${ }^{3}$ He ions may be likewise consumed via the reaction:

$$
\mathrm{D}+{ }^{3} \mathrm{He} \rightarrow{ }^{4} \mathrm{He}+{ }^{1} \mathrm{H}+18.4 \mathrm{MeV},
$$

which has an ignition temperature of $22 \mathrm{keV}\left(2.6 \times 10^{8} \mathrm{o} C\right)$. (1) The sequential reactions DD-DT and DD- $0^{3}$ He both release about $7 \mathrm{MeV}$ per deuteron consumed, as opposed to about $2 \mathrm{MeV}$ released per deuteron consumed by the $D-D$ reaction. This additional energy release provides incentive for maximizing the rates of these secondary reactions in a fusioning D-D plasma (at the expense of increased production of $14 \mathrm{MeV}$ neutrons).

other fusion reactions are also possible $e^{(2-5)}$ that involve isotopes of elements heavier than hydrogen and helium. The following reactions involving lithium, beryllium, and boron (B) are among those that have been considered:

$$
\begin{aligned}
& { }^{1} \mathrm{H}+{ }^{6} \mathrm{Li} \rightarrow{ }^{3} \mathrm{He}+{ }^{4} \mathrm{He}+4.0 \mathrm{MeV} \\
& 3_{\mathrm{He}}+6_{\mathrm{Li}} \rightarrow{ }^{7} \mathrm{H}+2{ }^{4} \mathrm{He}+16.9 \mathrm{MeV} \\
& D+{ }^{6} \mathrm{Li} \underset{{ }_{2}{ }_{2} \mathrm{H}+{ }^{7} \mathrm{Li}+5.0 \mathrm{MeV}}{{ }^{4} \mathrm{He}+17.5 \mathrm{MeV}}
\end{aligned}
$$

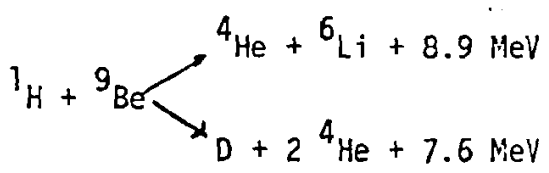

$$
\begin{aligned}
& 1_{H}+1_{B} \rightarrow 3^{4} \mathrm{He}+8.7 \mathrm{MeV} .
\end{aligned}
$$

The ignition temperatures for these reactions are higher than for the others, ranging up into the $\mathrm{MeV}$ range in some cases. The lithium and beryllium reactions are of particular interest for use in mirror reactors, which may be able to operate at high plasma temperatures. The beryllium reaction may be a candidate for use in advanced laser-ignited inertial confinement fusion reactors. The reactions in this latter group produce only charged particles. This has two potential consequences which are attractive. First, because the reactions are neutron free, reactor shielding requirements and structural activation might be reduced. Second, all of the released fusion 
energy would be available for direct conversion to electricity (in contrast to the D-T reaction where $80 \%$ of the energy is carried off by the neutrons and can only be recovered as heat).

In sumary, the first generation fusion reactors are expected to use the $D-T$ reaction because it is the easiest to achieve, and because deuterium and lithium used for tritium breeding are plentiful and inexpensive (in terms of their energy content). The appeal of the alternative fuel reactions lies in long-term availability of fuel, reduction of neutron production, elimination of necessity to breed tritium fuel through transmutation reactions, and enhanced potential for the direct-conversion generation of electricity. Fusion reactors using one of the alternative fuel reactions may exhibit reduced activation of blanket and structural materials, reduced inventories and effluents of radioactive tritium gas, and/or reduced waste heat per unit of electrical power by allowing more efficient electrical generation via direct conversion. Achievement of any or all of these possibilities might reduce the environmental impact of fusion reactors (although the occurrence of some unforeseen compensating factor might prevent $i t$ ).

Since all existing fusion power plant designs are based upon use of the D-T reaction, and since fusion reactors using $D-T$ fuel may have a greater environmental impact than as-yet-undesigned fusion reactors using alternative fuels, the environmental analysis for which this is a reference document assumes the use of D-T fuel and the need to breed tritium in the first generation fusion power plants.

\section{FUEL REQUI REMENTS}

The primary fuel materials for the first commercial fusion power plant are expected to be deuterium ( $D$ ) and tritium $(T)$. Lithium ( $L i$ ) and possibly beryllium (Be) in the blankets will be consumed in the production of the tritium, hence requirements for these materials are also discussed here. Fusion power plant requirements for these materials depend upon several factors:

- Consumption in nuclear reactions

- Recycle of partially consumed materials versus disposal as waste

- Isotopic enrichment feedstock requirements and tails disposition

- Blanket inventory requi rements.

The consumption of deuterium and tritium in nuclear reactions is primarily determined by plant power output and thermal efficiency. The corresponding consumption of lithium and beryllium are then determined by the tritium breeding ratio and by the required neutron multiplication per source neutron.

Tritium breeding consumes ${ }^{6} \mathrm{Li}$ preferentially in most designs, and solely in designs using highly enriched ${ }^{6} \mathrm{Li}$. Feedstock requirements for the enrichment process exceed the output of highly enriched ${ }^{6} \mathrm{Li}$ by 12 to 15 times because the abundance of ${ }^{6} \mathrm{Li}$ in natural lithium is only 7.5 percent. In the absence of demand for the enrichment tails of other industries the entire feedstock would be charged as a material requirement of fusion. However, if competition exists for lithium supplies, the enrichment tails would be a desirable source of chemical lithium for other industries. Consequently, needs for enriched and for natural lithium are discussed separately in this section. 
Conceptual fusion designs reviewed for this report have been prepared by a variety of study groups. Table 1 lists the laboratories from which they originated.

\section{TABLE 1 Originators of Conceptual Power Plant Designs}

\begin{tabular}{ll} 
Magnetic Confinement & \\
\hline Tokamak & $\begin{array}{l}\text { University of Wisconsin (UWMAK) } \\
\text { Brookhaven National Laboratory (BNL) } \\
\text { Princeton Plasma Physics Laboratory (PPPL) } \\
\text { Oak Ridge National Laboratory (ORNL) } \\
\text { Los Almos Scientific Laboratory (LASL) }\end{array}$ \\
$\begin{array}{l}\text { Mirror Pinch } \\
\text { Lawrence Livermore Laboratory (LLL) }\end{array}$ \\
$\begin{array}{ll}\text { Inertial Confinement } \\
\text { Wetted Wall }\end{array}$ \\
$\begin{array}{l}\text { Suppressed Ablation } \\
\text { LASL }\end{array}$
\end{tabular}

Fuel Consumption - Normalized annual consumption rates of deuterium, tritium, ${ }^{6} L i$ and beryllium in fusion nuclear reactions are presented in Table 2 for nine current conceptual fusion power plant designs.

TABLE 2 Normalized Annual Consumption of Fuel Materials by Nuclear Reactions

Power Plant Design

UWMAK-I Tokamak $(6)$
BNL Blanket for IWMAK I $(7)$
UWMAK-I I Tokamak $(8)$
PPPL Tokamak $(9)$
ORNL Tokamak $(10)$
Theta Pinch $(11)$
Mirror $(12)$
Wetted Wall Laser $(13)$
Suppressed Ablation Laser

Range
Consumption by Nuclear Reactions (metric tons/GWe-year)

\begin{tabular}{c} 
Net Plant \\
Thermal \\
Efficiency (\%) \\
\hline
\end{tabular}

\begin{tabular}{|c|c|c|c|}
\hline Deuterium & Tritium & ${ }_{L i^{a}}$ & Berylliumb \\
\hline 0.11 & 0.17 & 0.33 & - \\
\hline 0.11 & 0.16 & 0.32 & 0.24 \\
\hline 0.09 & 0.13 & 0.26 & 0.26 \\
\hline 0.07 & 0.10 & 0.20 & 0.07 \\
\hline 0.06 & 0.09 & 0.17 & - \\
\hline 0.09 & 0.13 & 0.30 & 0.15 \\
\hline 0.12 & 0.17 & 0.34 & - \\
\hline 0.11 & 0.16 & 0.31 & - \\
\hline 0.10 & 0.15 & 0.29 & - \\
\hline
\end{tabular}

$0.06-0.12 \quad 0.09-0.17 \quad 0.17-0.34 \quad 0.07-0.26$

a) Estimated roughly, assuming consumption of one atom of ${ }^{6} \mathrm{Li}$ per fusion neutron.

b) Estimated using specific Be reaction rate per fusion neutron for each reactor.

Deuterium consumption is seen to range from 0.06 to 0.12 metric tons per gigawatt-year $(1 \mathrm{GW}-\mathrm{yr}=1000 \mathrm{MW}-\mathrm{yr})$. The processing of spent plasma to remove impurities will doubtless entail some deuterium losses. Deuterium wastage has not been carefully studied, due to the large resources and low cost of this fuel material. Deuterium requirements may be 0.2 metric 
tons/GWe-yr including wastage. At this rate of usage a generating capacity of $10^{6}$ Me (which is about twice the total current U.S. generating capacity) would require 200 metric tons/year. However, because any wastage would be expected to return to the hydrosphere and be available for subsequent use the actual reduction of the deuterium resource would be less than 0.12 metric tons/GWe-yr.

Tritium fuel for fusion power plants will be bred from lithium in the reactor blankets and processed by plant systems. Present expectations are that fusion reactors will breed an excess of tritium. Doubling times* of less than a year are projected. Consequently, the only tritium supply required by the entire commercial fusion power industry is expected to be an initial inventory for the first large reactor. Plant inventories projected for current power plant designs are listed in Table 3. Active inventories (contained in blanket, coolant, and fuel systems) range up to a maximum of $9.2 \mathrm{~kg}$, and total inventories range up to $16 \mathrm{~kg} / \mathrm{GWe}$ of capacity. The maximum total inventory projected for a single plant is $23.5 \mathrm{~kg}$. Thus it is not expected that the entire commercial fusion power program will require the supply of more than $24 \mathrm{~kg}$ of tritium.

TABLE 3 Normalized Power Plant Tritium Inventories

Power Plant Design
UWMAK-I Tokamak
BNL Blanket for UWMAK-I
UWMAK-II Tokamak
PP)
PPPL Tokamak $(9)$
ORNL Tokamak $(10)$
Theta Pinch $(11)$

Range

\begin{tabular}{ccc}
\multicolumn{3}{c}{ Tritium Inventory per GWe Capacity, (kg) } \\
\cline { 1 - 2 } Active & Storage & Total \\
\cline { 2 - 3 } 9.2 & 6.8 & 16.0 \\
0.1 & 6.2 & 6.3 \\
3.0 & 3.6 & 6.6 \\
0.3 & 1.0 & 1.3 \\
0.8 & 10.8 & 11.6 \\
0.6 & 0.4 & 1.0
\end{tabular}

$0.1-9.2 \quad 0.4-10.8 \quad 1.0-16.0$

Consumption Due To Blanket Replacement - In all fusion power plant designs it is necessary to replace portions of the blanket periodically due to neutron damage. During replacement operations liquid blanket constituents such as liquid lithium metal or the molten salt flibe (LiF, BeF 2 mixture) can be drained and stored for reuse. Solid fertile and neutron multiplying materials specified in some designs, however, will be replaced along with the structural material since they are also subject to radiation damage. The recycle or disposal of these materials will then be determined by economics and the availability of materials. Differing assumptions about the need for, and efficiency of, recycle have been made for some designs. Estimates of annual make-up requirements for $1 i$ thium and beryllium are listed in Table 4. Power plant designs not included either lack estimates or have large inventories where burnup during the plant lifetime is sma11. Comparison of Tables 2 and 4 shows that annual makeup requirements range up to almost 50 times the amounts consumed by nuclear reactions for both lithium and beryllium. Annual makeup requirements of ${ }^{6} \mathrm{Li}$ will thus range from 0.3 to 12 metric tons per GWe capacity. 
Table 4 Normalized Annual Makeup Requirements of Lithium and Beryllium

Power Plant Design

BNL Blanket for UWMAK-I (6)

Tokamak

UWMAK-II Tokamak $(8)$

Theta Pinch (11)
Annual Makeup Quantity per GWe Capacity (metric tons)

Range
$0.3-12$
$0.6-11$

a) Natural 1 ithium required for enrichment feed is 12 to 15 times this amount.

b) 70 percent recycle assumed.

c) Solid lithium compound blanket.

d) 98 percent recycle assumed.

e) 90 percent recycle assumed.

f) Liquid lithium blanket.

An upper bound for ${ }^{6} \mathrm{Li}$ make-up requirements for a generating capacity of $10^{6}$ MWe is 12,000 metric tons per year. While recycle could reduce this requirement by a factor of 10 , the requirement for natural lithium feedstock for enrichment would be some 15 times larger than the ${ }^{6} \mathrm{Li}$ requirement.

Annual makeup requirements of beryllium range from 0.6 to 11 metric ton per GWe capacity. For a generating capacity of $10^{6}$ MWe, beryllium makeup requirements thus range up to 11,000 metric ton per year, even assuming recycle of more than 90 percent of the beryllium removed from reactor blankets. The spread of a factor of 20 in makeup requirements results from design differences and a variation of assumed recycle efficiency by a factor of five.

Inventory Requirements - To perform the functions of tritium breeding and neutron multiplication, fusion reactor blankets must contain more lithium and beryllium than is actually consumed.

Power plant inventories of these materials, normalized per GWe of plant output, are listed in Table 5.

Natural lithium inventories in designs lacking beryllium range from 4000 to 10,000 times the annual consumption (primarily of ${ }^{6} L i$ ) in nuclear reactions. These designs require no annual makeup of lithium, since consumption is trivial and liquid lithium is not subject to radiation damage. The inventory requirements for $10^{6}$ Me of generating capacity using these designs range from 500,000 to 1,200,000 metric tons, which is significant compared to resources. Since this material is not consumed or disposed of in power plant operation, these inventory requirements are not considered to be fuel requirements. Resource adequancy for plant construction is discussed in BNWL-2016. 
TABLE 5 Normalized Initial Power Plant Inventories of Lithium and Beryllium

Power Plant Design

UWMAK-I Tokamak $(6)$

BNL Blanket ${ }^{(7)}$ for UWMAK-I ${ }^{\text {b }}$

UWMAK-II (8) Tokamak ${ }^{\text {b }}$

PPPL (9) Tokamak ${ }^{\mathrm{C}}$

ORNL Tokamak (10)

Theta Pinch (11)

Mirror (12)

Inventory per GWe (metric tons)

$\frac{\text { Lithium }}{\text { Natural }} \underline{{ }_{L i}{ }^{a}} \quad$ Beryllium

$$
1,200
$$

$175 \quad 29 \quad 250$

3

-

$\begin{array}{ll}-\quad 3 & 120\end{array}$

$290 \quad-\quad 430$

890 -

$\begin{array}{lll}220 & 12 & 12\end{array}$

a) Natural ithium required for enrichment feed is 12 to 15 times this amount. b) Solid lithium compound blanket.

c) Flibe blanket ( $\mathrm{LiF}, \mathrm{BeF}_{2}$ mixture).

Inventories of enriched ${ }^{6} L i$ in designs which use it range from 25 to 240 times the annual consumption in nuclear reactions. Annual makeup of ${ }^{6} \mathrm{Li}$ for these designs ranges from $1 / 10$ to $1 / 2$ of the inventory and thus dominates plant requirements.

Inventories of beryllium metal in designs which use it range from 50 to 1000 times annual consumption in nuclear reactions. Annual makeup for designs which assume recycle ranges from $1 / 2$ percent to 5 percent when recycle is assumed, and thus exceed inventory requirements over the plant lifetime in the larger case.

The beryllium inventory in the flibe molten salt blanket is 2000 times annual consumption. No annual makeup is required since consumption is trivial and radiation damage does not require replacement.

Summary of Fuel Related Requirements - Operating fusion power plants are expected to require annual fuel related supplies per GWe of capacity as shown in Table 6 .

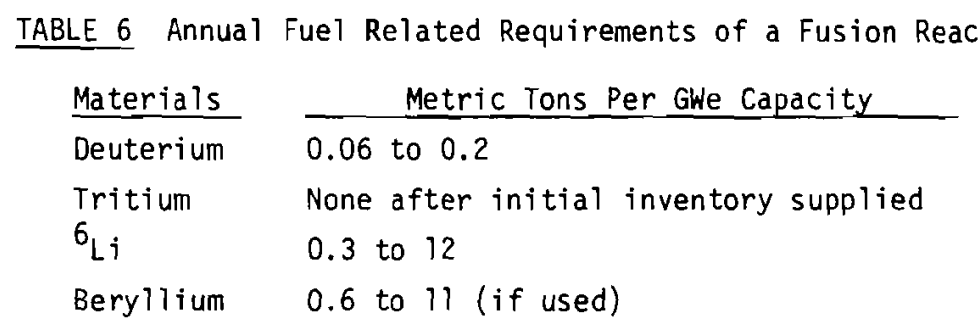

\section{FUEL RESOURCES}

Deuterium - Deuterium occurs as $\mathrm{D}_{2} \mathrm{O}$ in both sea water and fresh water. The concentration of $\mathrm{D}_{2} \mathrm{O}$ in the oceans is about 150 parts per million ( $\left.\mathrm{ppm}\right)$; in fresh water lakes and rivers it is somewhat less. Lake Superior, for example, is reported to contain about $148 \mathrm{ppm} \mathrm{D}_{2} 0$ with a seasonal variation of about 3 percent. (15) 
The enormity of the deuterium resources may be indicated by noting that the deuterium content of the earth's total water is on the order of $10^{13}$ metric ton. (16) Although the difficulty and cost for separating the deuterium will increase as it is consumed, a significant fraction of the earth's resource would have to be consumed before an effect would be noted. Consumption of less than 120 metric tons per year by a $10^{6}$ Me generating capacity is clearly trivial compared to this resource base.

Iritium - Cosmic radiation produces $1 / 2$ to $1 \mathrm{~kg} /$ year of tritium in the earth's atmosphere. This results in a natural inventory of 7 to $14 \mathrm{~kg}$ distributed throughout the earth's air and water, (17) which is unrecoverable due to its extremely low concentration. Therefore, tritium fuel for fusion reactors will be bred within the reactor blanket.

Lithium - Table 7 presents an estimate of U.S. Tithium reserves and resources. This estimate does not include lithium resources in the Great Salt Lake, estimated by the same author as 550,000 metric tons recoverable at three times present prices. (18) A more recent reserve estimate ${ }^{(6)}$ places U.S. lithium reserves recoverable at present prices at 500,000 metric tons, and recoverable at three times present prices at 3,890,000 metric tons. This latter estimate is comparable to the sum of the reserves and conditional resources in Table 7. Large lithium resources are also found elsewhere in the world. Notable examples are Canada with 116,000 metric tons of provable reserves and Rhodesia with 81,000 metric tons of provable reserves. (19)

An additional potential source of $1 i$ thium is the ocean, al though recovery probably would be very expensive compared to present sources. The ocean is estimated to contain 0.17 grams of lithium per cubic meter, or $2.5 \times 10^{13}$ metric tons for the total supply. ${ }^{(16)}$

As noted above, there is some agreement that the U.S. has at least 3,000,000 metric tons of lithium recoverable at a reasonable price. This is roughly a thousand times the feedstock required to supply the annual consumption of ${ }^{6} \mathrm{Li}$ by nuclear reactions of $10^{6}$ MWe generating capacity. Lithium resources therefore appear sufficient to support consumption by nuclear reactions for many centuries of $10^{6}$ Mwe generation.

The estimated U.S. 7 ithium resource of 3,000,000 metric tons is only 25 times the feedstock required to supply the maximum ${ }^{6} \mathrm{Li}$ makeup for $10^{6}$ MWe of generating capacity (UWMAK-II), assuming no recycle. If, however, 90 percent efficient recycle of enriched ${ }^{6} \mathrm{Li}$ removed from solid blanket concepts is implemented, 1 ithium resources appear sufficient to support more than a century of makeup requi rements for $10^{6}$ MWe of generation by these concepts. Finally, since the provision of enriched ${ }^{6}{ }_{L} i$ rejects more than 90 percent of the feedstock materials for possible use by other industries, greatly expanded chemical use of lithium should not impede provision of ${ }_{L} i$ for the fusion program.

Present plant designs using natural lithium coolant material require 500,000 to $1,200,000$ metric tons of inventory for $10^{6}$ Mwe of generating capacity. As was discussed in the previous section, insignificant burnup of lithium is expected in these plants over the entire assumed 30 year plant life. Consequently, this inventory could be recycled through successive generations of plants. Only makeup of ${ }^{6} \mathrm{Li}$ consumed in nuclear reactions would be required (along with the makeup due to planned continuous in-plant removal of impurities). Consequently, U.S. Iithium resources 
appear sufficient to support more than a century of $10^{6}$ Me generation by plants using natural lithium coolant/fertile material. Additional discussion of lithium resources is presented in BNWL-2016.

TABLE 7 U.S. Lithium Resources

\begin{tabular}{|c|c|c|c|}
\hline Locality & $\begin{array}{c}\text { Identifiec } \\
\begin{array}{c}\text { Proved } \\
\text { and }\end{array} \\
\text { Probable } \\
\text { Reserves }\end{array}$ & $\begin{array}{c}\text { Resources }^{\mathrm{a}} \\
\text { Possible } \\
\text { Reserves } \\
\text { and } \\
\text { Conditional } \\
\text { Resources } \\
\text { Res }\end{array}$ & $\begin{array}{l}\text { Hypothetical } \\
\text { Resources }\end{array}$ \\
\hline Kings Mountain, North Carolina & $270,000^{f}$ & e & 900,000 \\
\hline Black Hills, South Dakota & - & 9,000 & - \\
\hline $\begin{array}{l}\text { Other pegmatite districts } \\
\text { of the U.S. }\end{array}$ & - & 900 & - \\
\hline Silver Peak, Nevada (brine) & 41,000 & $1,800,000$ & $2,300,000$ \\
\hline $\begin{array}{l}\text { Salton Seal, California } \\
\text { (geothermal brine) }\end{array}$ & - & $1,000,000$ & - \\
\hline Searles Lake, California & 9,000 & 27,000 & - \\
\hline U.S. Total (rounded) & 320,000 & $2,840,900$ & $3,200,000$ \\
\hline
\end{tabular}

a) Specific, identified mineral deposits that may or may not be evaluated as to extent and grade, and whose contained minerals may or may not be profitably recoverable with existing technology and economic conditions.

b) Identified deposits from which minerals can be extracted profitably with existing technology and under present economic conditions.

c) Specific, identified mineral deposits whose contained minerals are not profitably recoverable with existing technology and economic conditions.

d) Undiscovered mineral deposits, whether of recoverable or subeconomic grade, that are geologically predictable as existing in known districts.

e) Included in hypothetical resources.

f) Reference 19 .

Beryllium - Beryllium is one of the rarest elements; the earth's average crustal abundance is only about $3 \mathrm{ppm}$. There are about 30 recognized minerals containing beryllium, of which only beryl $\left(3 \mathrm{BeO} \cdot \mathrm{Al}_{2} \mathrm{O}_{3} \cdot 6 \mathrm{SiO}_{2}\right)$ and bertrandite $\left[\mathrm{Be}_{4} \mathrm{Si}_{2} \mathrm{O}_{7}(\mathrm{OH})_{2}\right]$ are currently of commercial importance in the U.S. Beryl is a pegmatite mineral widely distributed throughout the world. The largest beryl resource in the U.S. is in the tin-spodumene belt in the southern Appalachians near Kings Mountain, North Carolina. The grade of this ore is only 0.4 percent beryl $(0.02$ percent beryllium) and recovery is likely to be as a byproduct from the mining of spodumene for lithi um. (6)

United States and world beryllium resources are not well known. Estimates of these quantities are shown in Table 8. The U.S. resource estimate of beryllium in nonpegmatitic, undiscovered deposits has been questioned. ${ }^{(8)}$ The total U.S. resources of beryllium are seen to be about 
285,000 metric tons. This is about a thousand times the maximum annual consumption in nuclear reactions for $10^{6}$ MWe generating capacity. It is, however, only about 25 times the maximum annual makeup required for $10^{6}$ Mhe of generating capacity, ${ }^{(8)}$ assuming recycle of 90 percent of the beryllium removed from the blanket. Resources appear inadequate to support such use of beryllium metal in large numbers of fusion reactor blankets, especially if there is competition for this resource by other industries.

Maximum and minimum requirements for annual beryllium makeup differ by a factor of 20 . Should designs using the minimum amount prove feasible, however, beryllium resources might support makeup requirements of $10^{6}$ WWe generating capacity for several hundred years with no competition from other sources. Factors causing the difference between the minimum and maximum requirements are:

- Half as large an inventory,

- Fifty percent longer assumed useful life in the blanket,

- One-fifth the losses assumed in recycle.

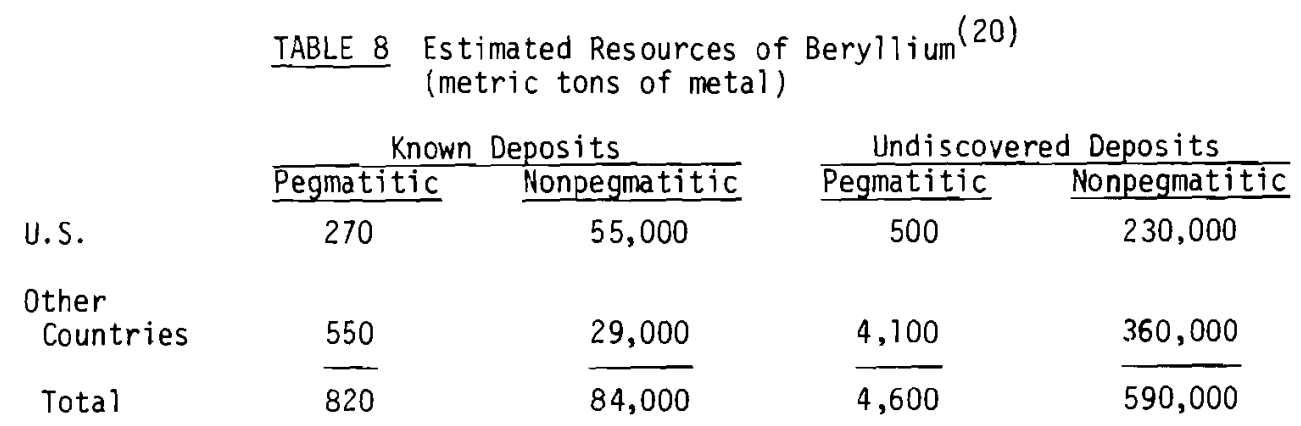

Each of these factors is design dependent and subject to change as a result of further engineering and development work. The uncertainty in the factors could be as large as the differences. Inventory requirements for $10^{6}$ MWe of generating capacity using either flibe in the blanket, or beryllium plus solid lithium compounds, exceed or are comparable to the estimated U.S. resources. Therefore, construction and operation of such a capacity for an extended period of time, in competition with beryllium demands from other industries, will not be possible unless estimates of beryllium resources can be increased. Additional discussion of beryllium resources is presented in BNWL-2016.

\section{FUEL SUPPLY}

\section{DEUTERIUM}

Supply Industry - Canada is presently the largest producer of deuterium in the form of heavy water, for use in CANDU (Canadian Deuterium Uranium) Reactors. Table 9 shows the current Canadian heavy water production capacity.

The capacity of these plants is large compared to forecast U.S. requirements. One heavy water plant in the U.S. could supply several times the deuterium required by fusion power plants generating $10^{6}$ Mwe. Alternatively, the U.S. might be able to purchase most of its $D_{2} O$ requirements from Canada. 
TABLE 9 Heavy Water Production Capacity in Canada

\begin{tabular}{lcll}
\multicolumn{1}{c}{ Plant Location } & $\begin{array}{c}\text { Capacity } \\
\text { (metric tons/year) }\end{array}$ & & \multicolumn{1}{c}{ Status } \\
\cline { 1 - 1 } Port Hawkesbury, Nova Scotia & 360 & & Operational \\
Glace Bay, Nova Scotia & 360 & & Operational \\
Bruce, Ontario & 800 & & Operational \\
Bruce, Ontario & 800 & & Under Construction \\
Bruce, Ontario & 800 & Approved \\
Gentilly, Quebec & 800 & Approved
\end{tabular}

The only operating U.S. heavy water plant is located at Savannah River, Georgia and is operated for the Energy Research and Development Administration (ERDA) by E. I. duPont de Nemours \& Co. The plant produces approximately 165 metric tons/year of $\mathrm{D}_{2} \mathrm{O}$ and has been operated since 1953. With sufficient maintenance it could conceivably be operated indefinitely, al though it might become more economic to construct a new facility before commercial introduction of fusion reactors. The current cost of deuterium is approximately $\$ 0.22 /$ gram. (21) The cost for the deuterium consumed in a fusion reactor would thus contribute less than $3 \times 10^{-3} \mathrm{mills} / \mathrm{kWh}$ to the electrical generating cost for a fusion power plant. Deuterium is currently available for sale from both the Savannah River facility and from the Canadian plants.

Production Methods. To produce deuterium from water, $\mathrm{D}_{2} \mathrm{O}$ is extracted, and deuterium then can be readily separated by electrolysis. The only significant environmental impact of the electrolytic process is the consumption of electricity. This impact is relatively small, however, in relation to other fuel extraction processes.

The method most used to produce large amounts of heavy water is the Guerdler Sulfide (GS) process. This process is used at Savannah River and at all of the Canadian plants. The GS process is a bithermal process based on the chemical exchange of hydrogen between hydrogen sulfide and Tiquid water. $(22,23) \quad \mathrm{D}_{2} 0$ tends to concentrate in water at low temperatures and in gaseous $\mathrm{H}_{2} \mathrm{~S}$ at elevated temperatures. $\mathrm{D}_{2} \mathrm{O}$ can be stripped from water and concentrated in a smaller volume of water by passing water and $\mathrm{H}_{2} \mathrm{~S}$ counter-currently first through a cold and then through a hot exchange column. Large quantities of water and $\mathrm{H}_{2} \mathrm{~S}$ are required. To produce one ton of $\mathrm{D}_{2} \mathrm{O}$, approximately 40,500 metric tons of water must be processed and 126,000 metric tons of $\mathrm{H}_{2} \mathrm{~S}$ cycled through the plant. (23)

Other processes proposed for comercial production of $\mathrm{D}_{2} 0$ include distillation, electrolysis, and chemical exchange reactions other than the GS process. Another technique that may be avai1able by the time deuterium is required for fusion power plants is laser separation. Significant progress on the laser separation of isotopes has recently been announced. (24) If successful, this technique might reduce the cost of $D_{2} 0$ production.

Environmental Impact. There are several impacts associated with production of $D_{2} \mathrm{O}$ by the GS process. A relatively large land area, on the order of several hundred acres, is needed for a large $D_{2} 0$ production facility. There is also an aesthetic impact from the plant, principally due to tall columns. The Savannah River plant minimized this impact with its remote location. 
$\mathrm{H}_{2} \mathrm{~S}$ is the environmental pollutant of greatest concern for a $\mathrm{O}_{2} \mathrm{O}$ plant using the GS process. Some $\mathrm{H}_{2} \mathrm{~S}$ is released in both liquid and gaseous effluents. Whenever possible, it is flared to $\mathrm{SO}_{2}$ to eliminate the odor of $\mathrm{H}_{2} \mathrm{~S}$. The estimated release rate of sulfur for the newer $\mathrm{D}_{2} \mathrm{O}$ plants is about 0.3 metric ton sulfur per metric ton of $\mathrm{D}_{2} \mathrm{O}$ produced. (25) If converted to $\mathrm{SO}_{2}$, this would be about 0.6 metric ton $\mathrm{SO}_{2}$ per metric ton of $\mathrm{D}_{2} \mathrm{O}$.

The environmental impacts of heavy water production are estimated for the 3200 metric tons/year Bruce A, B, C and D plants in Table 10, along with the fractions of these impacts which would correspond to the annual deuterium requirements of one 1000 MNe fusion power plant and of $10^{6}$ Me generating capacity. These impacts are essentially trivial.

TABLE 10 Primary Environmental Effects of Deuterium Production

\begin{tabular}{|c|c|c|c|}
\hline & \multicolumn{3}{|c|}{ Annual Effects } \\
\hline & $\begin{array}{l}\text { Bruce Heavy } \\
\text { Water Plant }\end{array}$ & $\begin{array}{l}\text { One } 1000 \text { Mwe } \\
\text { Fusion Reactor } \\
\end{array}$ & $\begin{array}{c}106 \text { MWe } \\
\text { Generating } \\
\text { Capacity }\end{array}$ \\
\hline $\begin{array}{l}\text { Deuterium Production } \\
\text { (metric tons per year) }\end{array}$ & 640 & 0.066 & 66 \\
\hline Land Area (acres) & 10,300 & 1.1 & 1,060 \\
\hline $\begin{array}{l}\text { Coal Usage (metric tons per } \\
\text { year) }\end{array}$ & $3,000,000$ & 300 & 300,000 \\
\hline $\begin{array}{l}\text { Water Usage (gallons per } \\
\text { minute) }\end{array}$ & $1,400,000$ & 140 & 140,000 \\
\hline $\begin{array}{l}\text { Heat Release (megawatts } \\
\text { thermal) }\end{array}$ & 1,850 & 0.2 & 190 \\
\hline Release to Water & & & \\
\hline $\mathrm{H}_{2} \mathrm{~S}$ (kilograms per year) & $<2,300$ & $<0.24$ & $<240$ \\
\hline Salts & 2,000 & 0.2 & 200 \\
\hline Releases to Air ${ }^{b}$ & & & \\
\hline $\mathrm{SO}_{2}$ (metric tons per year) & 30,000 & 3 & 3,000 \\
\hline $\mathrm{NO}_{\mathrm{X}}$ (metric tons per year) & 10,000 & 1 & 1,000 \\
\hline $\begin{array}{l}\text { Solid waste (metric tons per } \\
\text { year) }\end{array}$ & $10,000,000$ & 1,000 & $1,000,000$ \\
\hline Operating Employees & 600 & 0.06 & 60 \\
\hline
\end{tabular}

a) Assumes steam provided by a coal-fired power plant with 2000 MWt capacity. b) Reference 25 .

\section{$\underline{\text { TRITIUM }}$}

Production of First Reactor Inventory - The only tritium supply needed by the U.S. commercial fusion power program will be the initial inventory of the first plant. This is not expected to exceed $24 \mathrm{~kg}$. Several potential sources are listed and discussed below.

- Acquisition from the U.S. stockpile.

- Production in a U.S. Light Water Reactor.

- Purchase from production in a Canadian Heavy Water Reactor. 
- Production in a U.S. Heavy Water Power Reactor.

- Production in an LMFBR.

- Production in a special purpose reactor.

The U.S. stockpiles of tritium are kept for national security purposes and may not be available for commercial uses.

Production of tritium by insertion of $1 i$ thium bearing target elements in U.S. fission reactors is a possibility. The production would most likely have to be in commercial power reactors, because the Federally owned Savannah River reactors may not be operational late in this century. They have been operating and producing tritium since the early 1950s. Hennelly (26) has estimated that $40 \mathrm{~kg}$ of tritium could realistically be produced in fission reactors between 1985 and 2000 provided there is adequate preplanning. This would be a sufficient quantity for any of the proposed fusion reactor designs.

Production of tritium in a power producing heavy water reactor (HWR) is another potential source. HWRs, which have on-line fueling, offer an advantage over light water reactors (LWRs) which have fueling periods of up to one and one half years. Tritium could conceivably be produced in a Canadian HWR and purchased by the U.S. The U.S. could al ternatively purchase a HWR for construction in the U.S. Such a reactor would likely have to be Federally owned, since private interests may not be interested in constructing only one or two special purpose HWRs.

Finally, the U.S. could construct a special purpose reactor to produce tritium. A production reactor would be a more efficient tritium producer than a power reactor. However, considering the necessary capital investment it would also be much more costly.

Environmental Impact - The largest environmental impact associated with tritium production would occur if a special reactor were constructed to produce the tritium. The impact associated with construction of the reactor would be comparable to that of an LWR.

The release of tritium produced in a special purpose reactor or in a commercial LWR or HWR would be kept small for both economic and environmental reasons. Current LWRs release as little as 20 curies of tritium per year of operation. In reactors producing tritium as a by-product to the production of electricity, tritium production probably would not add significantly to the total amount of tritium released to the environment. The only additional releases would be the small amount that might leak out of target elements because of diffusion through the cladding, cladding failures, and losses during recovery processes.

\section{$\underline{\text { LITHIUM }}$}

Supply Industry - U.S. 1ithium production increased from approximately 1570 metric tons (27) in 1969 to 2760 metric tons ${ }^{(28)}$ in 1974. This represents an annual compounded growth rate of about 12 percent. If growth continues at this rate, annual production in 1999 wi 11 be nearly 55,000 metric tons. This is large compared to the largest lithium requirement for construction of a single fusion power plant, which is 1700 metric tons for UWMAK-I. Cumulative production by 1999 would be 390,000 metric tons of lithium which is relatively small compared to the total U.S. resource. 
Concern has been expressed over the ability of the lithium industry to meet demand toward the end of this century. (30) The possible successful development of lithium-sulfur storage batteries (electric automobiles; utility off-peak storage) may require a ten-fold increase in lithium production and consume up to $1,000,000$ metric tons of lithium.

Due to the high energy content of lithium as a fusion fuel, however, significant lithium price increases could be tolerated with little effect on projected electric power costs. This would allow fusion reactors to compete favorably for supplies, and also allow the exploitation of lower-grade resources. For example, at the maximum ${ }^{6} \mathrm{Li}$ comsumption rate due to nuclear reactions of $340 \mathrm{~kg} /$ GWe-year the energy content of the lithium consumed is 20,000 kWh per gram. The ${ }^{6} \mathrm{Li}$ enrichment cost is not known at present for a large commercial facility. If it is assumed to be 10 times the present cost of natural lithium of $\$ 15$ per pound, this consumption by nuclear reactions would yield a lithium fuel cost of $0.02 \mathrm{mills} / \mathrm{kWh}$. Increasing this by a factor of 40 to include required makeup of ${ }^{6} \mathrm{Li}$ due to blanket replacement would still yield a lithium fuel cost of less than one mill/kWh.

Production Methods - Lithium is produced from pegmatite ores and from brines in the U.S. The pegmatite deposit in the Kings Mountain area of South Central North Carolina is the largest pegmatite deposit in the U.S. (32) Lithium is contained in the mineral spodumene ( ${ }^{2}$ AAISi $\left._{2}{ }_{6}\right)$ ) which is contained in pegmatite. An open pit process is used to mine the ore. Spodumene is recovered from the ore by crushing, screening, grinding, and flotation operations. Lithium compounds are recovered from chemical grade spodumene by calcination followed by leaching and evaporation-crystallization or treatment with sulfuric acid followed by soda ash. (19)

The Black Hills area of South Dakota is the next most important pegmatite source of lithium. (18) The principal lithium mineral there is also spodumene.

As Table 7 indicates, brines are the largest potential source of lithium. The dry lake brine deposit currently being worked at Silver Peak, Nevada, is the largest domestic lithium resource. The other brine deposit being worked is located at Searles Lake in California. Other brine sources are the Salton Sea, also in California, and the Great Salt Lake.

At Silver Peak, brine is pumped from wells into solar evaporation ponds. The brine is sequentially evaporated through several ponds until a 6 percent lithium chloride content is obtained. (31) The final product, lithium carbonate, is precipitated from the concentrated brine by the addition of sodium carbonate.

At Searles Lake dilithium sodium phosphate is obtained as a by-product from solar evaporation. This product is treated with sulfuric acid and soda ash to produce lithium carbonate.

Environmental Impact - The principal impact of lithium production from both pegmatites and brines is the land requirement. This is somewhat different for each source.

In the largest pegmatite source area, the Kings Mountain tin-spodumene belt of North Carolina, lithium ore is surface mined. The belt is about 30 miles long and less than one mile in average width. (32) The maximum land area that could be disrupted is consequently less than 30 square miles. Extensive land reclamation has not yet begun in the Kings Mountain area but should be initiated as areas are mined out. Process water in the Kings Mountain area is taken from creeks. The water is recirculated and reused. (32) 
The largest brine source of lithium is a dry lake bed in an isolated area near Silver Peak, Nevada. The lithium underlies a 32 square mile basin. ${ }^{(18)}$

After the brine is extracted from the ground it is evaporated in large ponds. Evaporation leaves significant quantities of salts that are kept on the ground. Leaching of the salts into the ground will preclude use of the land for agriculture indefinitely. Use for agriculture would be uncertain in any case because of the shortage of water in the area. A small proportion of the spent brine is returned underground.

\section{BERYLLIUM}

Supply Industry - U.S. production of beryllium from 1969 to 1973 averaged about 320 metric tons per year. This is about 20 times larger than the annual makeup requirements for one power plant of the UWMAK-II design, but one-third smaller than its inventory requirement. It is less than 40 percent of the inventory required for one power plant of the PPPL tokamak design. Construction of such power plants would clearly require major expansion of industry capacity.

Although the present beryllium price of $\$ 155$ per pound ${ }^{(33)}$ is rather high, the contribution of beryllium costs to electricity costs is not large. At the maximum consumption rate due to nuclear reactions of $260 \mathrm{~kg} /$ GWe-year the cost for beryllium would be $0.01 \mathrm{mill} / \mathrm{s} / \mathrm{kWh}$. Increasing this by a factor of 40 to include the maximum required makeup due to blanket replacement would still yield a beryllium fuel cost of less than half a mill/ kWh.

Production Methods - In recent years the largest domestic source of beryllium has been the Spor Mountain bertrandite mine near Delta, Utah. ${ }^{(34)}$ The U.S. Bureau of Mines has estimated the amount of beryllium in domestic bertrandite deposits at 25,200 metric tons ${ }^{(35)}$ most of which is at Spor Mountain. Brush Weliman, Inc, operators of the Spor Mountain mine, convert the bertrandite ore to beryllium hydroxide which is then further converted to beryllium metal and other compounds. (34)

It is not possible to generate beryllium by smelting beryl in the normal sense, i.e., to convert the ore to beryllium metal plus slag. Consequently, beryl is chemically treated to produce beryllium oxide which is then used for metal preparation. There are two commercial processes for recovery of beryllium oxide from beryl, ${ }^{(36)}$ the fluorine process and the sulfate process. In the fluorine process, beryllium is selectively extracted by roasting bery 1 with sodium fluorosilicate and leaching with water. In the sulfate process, beryl is rendered soluble by heat treatment and decomposed by sulfuric acid. Beryllium is then dissolved in water. Each process yields about 90 percent of the beryllium in the starting ore. Two processes are used to convert beryllium oxide to beryllium metal. They are the reduction of beryllium fluoride with magnesium and the electrolys is of beryllium chloride.

Environmental Impact - The extraction of beryllium ore from the ground does not result in a greater environmental impact than other types of mining. Both open pit and underground mining are used. The most significant impact for each operation is 1 and disruption. The quantity of land disrupted may become large if it is necessary to mine low grade ore. Sound land conservation and restoration practices can return the mining areas to nearly pre-mining conditions within several years. Land reclamation is practiced at the Spor Mountain mine. 
Toxicity - The most significant environmental impact associated with beryllium results from its toxicity. Although the ores of beryllium have not been found to be hazardous, all simple beryllium compounds $\left[\mathrm{BeF}_{2}, \mathrm{BeO}, \mathrm{Be}(\mathrm{OH})_{2}, \mathrm{BeSO}_{4}, \mathrm{BeCl}_{2}\right.$, etc. $]$ appear to be toxic. ${ }^{(36)}$

Beryllium and its compounds are capable of inducing adverse chronic and acute pathological effects in a number of human tissues. ${ }^{(37)}$ Beryllium enters the body almost exclusively by inhaling beryllium materials such as dust, smoke, or aerosols. (38) Inhaling these materials can lead to pneumonitis, a chronic disease of the lung tissue. The chronic effects of exposure to low concentrations of beryllium materials may not appear until several years after exposure. The effects may include pneumonitis with a cough, chest pain, loss of weight, and general weakness. Exposure can also lead to contact dermatitis.

Acute beryllium disease results from irritation of the respiratory tract with pneumonitis. It is associated with exposure to high beryllium concentrations (above 100 micrograms per cubic meter of air). (39) Onset of the acute disease occurs within a week. Other acute health effects of beryllium include ocular (eye) ulcers, rhinitis (inflammation of the nose), pharyngitis (inflammation of the throat), and tracheobronchitis (inflammation of the mucous membrane of both trachea and bronchi). All of these effects are reversible if exposure is low. (29)

A Beryllium Case Registry has been kept at Massachusetts General Hospital since 1952. Of a total of 837 cases, only 76 have been entered since 1966. Most cases were the result of exposure prior to the recommendation of a beryllium concentration limit of two micrograms per cubic meter of air in 1949. This limit is now enforced by the Occupational Safety and Health Administration. It is not entirely clear whether this limit is completely safe. However, one laboratory (LASL) that has adhered closely to the limit has reported no cases of beryllium disease. (40)

The toxicity of beryllium requires close attention to cleanliness in milling and fabrication processes. Industry is aware of the hazard and has developed procedures for various operations to assure as low as practicable exposure to workers. These procedures include special building ventilation, hooding, and other precautions for certain individual work areas, careful laundering of work clothing, and shower facilities for employees.

\section{REFERENCES}

1. H. K. Forsen, Some Technological Problems in Fusion Reactor Design, UWFDM 11, University of Wisconsin, Mar 1972.

2. V. S. Crocker, S. Blow and C. J. H. Watson, Nuclear Cross Section Requirements for Reactors, IAEA-CN-26198, 1970.

3. W. C. Gough and B. J. Eastlund, The Prospects for Fusion Power, Scientific American, Feb 1971 .

4. J. Rand McNally, Fusion Chain Reactions-1, Nuclear Fusion 11, 1971.

5. UCRL-60021-73-1, Laser Fusion Semiannual Report - January/June 1973, Lawrence Livermore Laboratory Report, p. 209.

6. B. Badger, et a1., (30 authors), UWMAK-I, A Wisconsin Toroidal Fusion Reactor Design, UWFDM-68, University of Wisconsin, Vol. I (1974) and II (1975). 
7. J. R. Powel1, Ed., "Preliminary Reference Design of a Fusion Reactor Exhibiting Very Low Residual Radioactivity," BNL-19565, Brookhaven National Lab., Dec 1974.

8. B. Badger, et a1., (30 authors), UWMAK-II, A Conceptual Tokamak Power Reactor Design, UWFDM-112, University of Wisconsin, 0ct 1975.

9. A Fusion Power Plant, R. G. Mills, Ed., MATT-1050, Princeton Plasma Physics Laboratory, 1974.

10. A. P. Fraas, Conceptual Design of the Blanket and Shield Region and Related Systems for a Full Scale Toroidal Fusion Reactor, ORNL-TM-3096, May 1973.

11. An Engineering Design Study of a Reference Theta-Pinch Reactor (RIPR), no author 26 contributors, LA-5336, ANL-8019, (Joint report), Vols. I (1974) and II (1975).

12. R. W. Werner, G. A. Carlson, J. Hovingh, J. D. Lee and M. A. Peterson, Progress Report \#2 on the Design Considerations for a Low Power Experimental Mirror Fusion Reactor, UCRL-74054-2, Sep 1973.

13. J. Williams, T. Merson, F. Finch, F. Schilling, and T. Frank, A Conceptual Laser Controlled Thermonuclear Reactor Power Plant, LA-UR-74-593, Los ATamos Scientific Laboratory, Los ATamos, NM, Apr 1974.

14. J. Hovingh, J. Maniscalco, M. Peterson and R. W. Werner, "The Preliminary Design of a Suppressed Ablation Laser-Induced Fusion Reactor," Proceedings of the First Topical Meeting on the Technology of Controlled Nuclear Fusion, April 16-18, 1974, San Diego, CA, CONF-740402-P1, P. 96.

15. J. A. Ayres, Production of Heavy Water - Status Report, BNWL-884, Battelle, Pacific Northwest Laboratory, 1969.

16. J. P. Holden, Adequacy of Lithium Supplies as a Fusion Energy Source, UCID-15953, 1971.

17. D. G. Jacobs, Sources of Tritium and Its Behavior Upon Release to the Environment, TID 24635, NBS, U.S. Department of Commerce, Health Physics Division, Nuclear Safety Information Center, Oak Ridge National Laboratory, 1968.

18. J. J. Norton, Unless otherwise indicated, all numbers in the table are from James J. Norton, "Lithium, Cesium, and Rubidium - The Rare Alkali Metals," in, United States Mineral Resources, U.S. Geological Survey Professional Paper 820, 1973.

19. T. A. Kunasz, "Lithium Raw Materials," Industrial Minerals and Rocks, AIME Edition, 1974.

20. W. R. Griffiths, "U.S. Mineral Resources - Beryllium," U.S. Geological Survey Professional Paper 820, U.S. Government Printing Office, 1973.

21. D. J. Rose, "Fusion Frontiers," in National Materials Policy, National Academy of Sciences, Washington, D.C., 1975.

22. Ayres, 1967.

23. J. J. Katz, "Chemical and Biological Studies with Deuterium," Thirty-Ninth Annual Priestley Lectures at the Pennsylvania State University, 1965.

24. Chemical \& Engineering News, May 5, 1975, p. 4.

25. Atomic Energy of Canada, Ltd, "Environmental Report for the LaPrade Heavy Water Plant," Jun 1975.

26. E. J. Hennelly, "Fuel and Blanket Management and Supply in Commercial Fusion," Proceedings of the First Topical Meeting on the Technology of Controlled Thermonuclear Reactors, Technical Report ESL-10, Energy Systems Laboratories, the University of Texas at Austin, Apr 1973. 
27. "Lithium Production Fails to Keep Pace with Growing Markets," Industrial Minerals, Jut 1974.

28. W. F. Luchenbach, "Lithium - Burgeoning Demand Will Require New Production," Engineering and Mining Journal, Mar 1975.

29. UWMAK-I, The University of Wisconsin Fusion Feasibility Study Group, A Wisconsin Toroida 1 Fusion Reactor Design, Vol. II, 1975.

30. A. L. Hammond, "Lithium: Will Short Supply Constrain Energy Technologies," Science, 191:1037, Mar 12, 1976.

31. "Nevada Brine Supports a Big New Lithium Plant," Chemical Engineering, Aug 15, 1966.

32. N. Johnson, "Foote Mineral Company's Lithium Mining Operations at Kings Mountain, North Carolina," The Mines Magazine, Apr 1960.

33. Engineering and Mining Journal, p. 61, McGraw-Hi11, Jun 1975.

34. R. A. Whitman, "Beryllium," in Minerals Yearbook 1972, Vo1. 1, U.S. Department of the Interior, 1974.

35. U.S. Bureau of Mines, Conmodity Data Sunmaries, 1974.

36. D. A. Everest, The Chemistry of Beryllium, Elsevier Publishing Co., New York, 1964.

37. H. H. Hausner, Beryllium: Its Metallurgy and Properties, University of California Press, p. $298,1965$.

38. I. R. Tabershaw, The Toxicology of Beryllium, U.S. Department of Health, Education and Welfare, PHS Publication No. 2173, 1972.

39. G. E. Darwin and J. H. Buddery, Beryllium, Academic Press, Inc., New York, p. 369, 1960.

40. "Beryllium's Environment, Vol. 16, No. 3, 1974, p. 35., reprinted from Medical World News, McGraw-Hill, Inc., Oct 26, 1973. 
A. A. Churm ERDA Chicago Patent Group $9800 \mathrm{~S}$. Cass Avenue Argonne, IL 60439

J. W. Beal

ERDA Div. of Magnetic Fusion Energy Washington, DC 20545

S. 0. Dean

ERDA Div. of Magnetic Fusion Energy

Washington, DC 20545

E. E. Kintner

ERDA Div. of Magnetic Fusion Energy Washington, DC 20545

J. M. Williams ERDA Div. of Magnetic Fusion Energy Washington, DC 20545

J. N. Grace

ERDA Div. of Magnetic Fusion Energy Washington, DC 20545

J. Baublitz

ERDA Div. of Magnetic Fusion Energy Washington, DC 20545

3 F. E. Coffman ERDA Div. of Magnetic Fusion Energy Washington, DC 20545

J. F. Decker

ERDA Div. of Magnetic Fusion Energy Washington, DC 20545

3 K. M. Zwilsky ERDA Div. of Magnetic Fusion Energy Washington, DC 20545

Dr. Philip M. Stone

ERDA Applied Plasma Physics

Program

Washington, DC 20545

G. W. Kuswa

ERDA Div. of Laser Fusion Washington, DC 20545
R. Blaunstein

ERDA Div. of Biomedical and Environmental Research Washington, DC 20545

H. M. Busey

ERDA Div. of Military

Application

Washington, DC 20545

M. A. Bell

ERDA Div. of Safety

Standards and Compliance

Washington, DC 20545

27 ERDA Technical Information Center

M. S. Kaminsky

Argonne National Laboratory

$9700 \mathrm{~S}$. Cass Avenue

Argonne, IL 60439

V. A. Maroni

Argonne National Laboratory

$9700 \mathrm{~S}$. Cass Avenue

Argonne, IL 60439

P. M. Persiani

Argonne National Laboratory

9700 S. Cass Avenue

Argonne, IL 60439

M. Petrick

Engineering and Technology Division

Argonne National Laboratory

9700 S. Cass Avenue

Argonne, IL 60439

W. E. Parkins, Manager

Atomics Internationa?

Component Engineering and

Technology Division

North American Rockwe 11

P. 0. Box 309

Canoga Park, CA 91304

D. Gurinsky

Brookhaven National Laboratory

ERDA Brookhaven Area Office

Upton, NY 11973

H. J. Kouts

Brookhaven National Laboratory ERDA Brookhaven Area Office Upton, NY 11973

S. Pearlstein

Brookhaven National Laboratory ERDA Brookhaven Area Office

Upton, NY 11973

\section{OFFSITE}

J. R. Powell

Brookhaven National Laboratory ERDA Brookhaven Area Office

Upton, NY 11973

A. J. Impink, Jr. Carnegie Mellon University Pittsburgh, PA 15213

R. A. Gross

Plasma Research Laboratory

236 SW Mudd Bidg.

Columbia University

New York, NY 10027

W. C. Gough

Electric Power Research Inst.

3412 Hillview Ave.

Palo Alto, CA 94304

G. R. Hopkins

Gulf General Atomic

P.0. Box 1111

San Diego, CA 92112

Zeinab Sabri

Iowa State University

261 Sweeney Hall

Nuclear Engineering Department

Ames, IA 50010

R. Borg

Lawrence Livermore Laboratory

P.0. Box 808

Livermore, CA 94550

T. K. FowTer

Lawrence Livermore Laboratory

P.0. Box 808

Livermore, CA 94550

R. Moir

Lawrence Livermore Laboratory

P.0. Box 808

Livermore, CA 94550

A. Carl Haussmann

Lawrence Livermore Laboratory

P.0. Box 808

Livermore, CA 94550

J. Hovingh

Lawrence Livermore Laboratory

P.0. Box 808

Livermore, CA 94550

R. F. Post

Lawrence Livermore Laboratory

P.0. Box 808

Livermore, CA 94550

C. J. Taylor

Lawrence Livermore Laboratory

P.0. Box 808

Livermore, CA 94550 
$R$. Werner

Lawrence Livermore

Laboratory

P.0. Box 808

Livermore, CA 94550

L. L. Wood

Lawrence Livermore

Laboratory

P.0. Box 808

Livermore, CA 94550

W. Bauer

Division Supervisor

of Physical Research

Sandia Labs Livermore

Livermore, CA 94550

L. Booth

Los Alamos Scientific

Laboratory

CTN Research

P.0. Box 1663

Los Alamos, NM 87544

D. J. Dudziak

Los Alamos Scientific Laboratory

CTN Research

P.0. Box 1663

Los Alamos, NM 87544

D. B. Henderson

Los Alamos Scientific

Laboratory

CTN Research

P.0. Box 1663

Los Alamos, NM 87544

E. L. Kemp

Los Alamos Scientific

Laboratory

CTN Research

P.0. Box 1663

Los Alamos, NM 87544

F. L. Ribe

Los Alamos Scientific

Laboratory

CTN Research

P.0. Box 1663

Los Alamos, NM 87544

L. Stewart

Los Alamos Scientific

Laboratory

CTN Research

P.0. Box 1663

Los Alamos, NM 87544

K. Thomassen

Los Alamos Scientific Laboratory

CTN Research

P.0. Box 1663

Los Alamos, NM 87544
0. K. Harling

Massachusetts Institute of

Technology

Cambridge, MA 02139

Bruno Coppi

Department of Physics

Massachusetts Institute of

Technology

Cambridge, MA 02139

L. Lidsky

Dept. of Nuclear Engineering

Massachusetts Institute of

Technology

Cambridge, MA 02139

Norm Rasmussen

Dept. of Nuclear Engineering

Massachusetts Institute of

Technology

Cambridge, MA 02139

David Rose

Massachusetts Institute of

Technology

Cambridge, MA 02139

R. E. Stickney

Mechanical Engineering

Massachusetts Institute of

Technology

Cambridge, MA 02139

J. J. Reinmann

NASA - Lewis Research Center

2100 Bookpark Rd.

Cleveland, $\mathrm{OH} 44135$

Vincent Arp

National Bureau of Standards

Cryogenics Division

Boulder, C0 80302

J. F. Clarke

Oak Ridge National

Laboratory

P.0. Box Y

Oak Ridge, TN 37830

A. P. Fraas

Oak Ridge National

Laboratory

P.0. Box $Y$

Oak Ridge, TN 37830

J. Rand McNally, Jr.

Oak Ridge National

Laboratory

P.0. Box $Y$

Oak Ridge, TN 37830

D. Steiner

Oak Ridge National

Laboratory

P.0. Box Y

Oak Ridge, TN 37830
OFFSITE

J. $S \operatorname{cott}$

Oak Ridge National Laboratory

P. 0. Box $X$

Oak Ridge, TN 37830

J. Banford

Physics International

2700 Merced St.

San Leandro, CA 94577

R. A. Huse

Public Service Electric

and Gas Co.

80 Park Place

Newark, NJ 07101

M. Gottlieb

Princeton University, PPPL

P.0. Box 451

Princeton, NJ 08540

R. G. Mills

Princeton University

P. 0 . Box $45 i$

Princeton, NJ 08540

E. C. Tanner

Princeton University

P.0. Box 451

Princeton, NJ 08540

H. Perkins

Dept. of Chemistry

Princeton University

Princeton, NJ 06540

R. E. Gold

303 Sayre Hall

Forrestal Campus

P.0. Box 451

Princeton, NJ 06540

M. Kristiansen

Texas Tech. University

Lubbock, TX 79409

A. F. Haught

United Aircraft Research Lab.

United Aircraft Corporation

East Hartford, CT 06108

L. Levine

U.S. Naval Research Laboratory

Washington, DC 20390

C. Z. Serpan, Jr.

U.S. Naval Research Laboratory

Washington, DC 20390

Francis Chen

University of California

Electronics Research

Laboratory

College of Engineering

Berkeley, CA 94720 
A. J. Lichtenberg University of California Electronics Research Laboratory

College of Engineering

Berkeley, CA 94720

Dave Okrent

U.C.L.A.

Los Angeles, CA 90024

C. D. Hendricks

University of 111 inois

Nuclear Engineering

Laboratory

Urbana, IL 61801

\section{G. H. Miley}

University of Illinois

Nuclear Engineering

Laboratory

Urbana, IL 61801

Terry Kammash

University of Michigan

Nuclear Engineering

Department

Ann Arbor, MI 48105

Dean Abrahamson

University of Minnesota

School of Public

Affairs

Social Science

Building/309

Minneapolis, MN 55455

W. G. Davey

University of Texas

Department of Physics

Austin, TX 78712

E. Linn Draper, Jr. University of Texas Department of Physics Austin, TX 78712

W. E. Drummond University of Texas Department of Physics Alistin, TX 78712

Abraham Hertzberg University of Washington Aerospace Research Laboratory

316 Guggenheim Seattle, WA 98105

A. L. Babb

University of Washington Nuclear Engineering Department

Seattle, WA 98105
R. Conn

University of Wisconsin

Nuclear Engineering

Department

Madison, WI 53706

G. L. Kulcinski University of Wisconsin Nuclear Engineering Department

Madison, WI 53706

C. W. Maynard University of Wisconsin Nuclear Engineering

Department

Madison, WI 53706

D. Lichtman Department of Physics University of Wisconsin Milwaukee, WE 53201

E. E. Donaldson

Washington State University Deparment of Physics

Pullman, WA 99163

D. D. Mahlum Division of Biomedical and Environmental Research Washington, DC 20545

\section{J. V. Vanston}

Engineering Science

Building

University of Texas

Austin, TX 78712

Leslie S. Ramsey

450 North 5 th Street

Indiana, PA 15701 
ERDA Richland Operations Office

W. A. Burns

Atlantic Richfield Hanford Company

J. D. Kaser

Hanford Engineering Development Labs

D. G. Doran

H. H. Yoshikawa

Battelle-Northwest

D. T. Aase

G. S. Allison

T. W. Ambrose

D. G. Atteridge

D. A. Baker

J. L. Bates

M. A. Bayne

E. R. Bradley

J. L. Brimhall

R. L. Brodzinski

R. J. Brouns

L. R. Bunnell

L. L. Burger

S. H. Bush

N. E. Carter

T. D. Chikalla

R. G. Clark

T. L. Criswell

S. D. Dahlgren

M. T. Dana

D. E. Deonigi

R. L. Dillon

D. A. Dingee

P. J. Dionne

B. H. Duarie

J. W. Finnigan

J. C. Fox

J. J. Fuquay

J. E. Garnier

R. D. Gastil

10 B. F. Gore

J. N. Hartley

A. J. Haverfield

U. P. Jenquin

A. B. Johnson, Jr.

R. H. Jones

T. J. Kabele

W. S. Kelly

H. E. Kissinger

D. A. Kottwitz

N. Laegried

B. R. Leonard, Jr

D. L. Lessor

H. B. Liemohn

R. C. Liikala

M. A. Mckinnon

R. F. Maness

R. P. Marshall
Battelle-Northwest - Continued

E. S. Murphy

R. D. Nelson

D. F. Newman

R. E. Nightingale

D. E. Olesen

L. T. Pedersen

R. T. Perry

D. R. Pratt

L. A. Rancitelli

J. F. Remark

U. S. Renné

R. E. Rhoads

W. D. Richmond

W. F. Sandusky

L. C. Schmid

N. M. Sherer

E. P. Simonen

R. I. Smith

J. K. Soldat

C. W. Stewart

K. B. Stewart

R. W. Stewart

J. A. Strand

D. L. Styris

A. M. Sutey

V. L. Teofilo

G. L. Tingey

M. T. Thomas

R. C. Thompson

L. H. Toburen

T. J. Trapp

R. Wang

R. E. Westerman

L. D. Williams

10 J. R. Young

M. G. Zimmerman

1 Technical Publications (BH)

5 Technical Information 